\title{
HOW IMPORTANT ARE TODAY'S TEACHER DEVELOPMENT PROGRAM CONTENTS FOR PRIMARY SCHOOL TEACHER?
}

\author{
Jayanti \& Dinn Wahyudin \\ Post-graduate School of Curriculum Development, Universitas Pendidikan Indonesia, \\ e-mail: jayanti2016@student.upi.edu
}

\begin{abstract}
Teacher development program (TDP) will only be effective when it answers the teacher's need. This study aims to find out how important the training content that has been delivered in the TDP. The training contents listed in this study drawn from the Teacher Working Group, the School of Master Teacher program organized by Sekolah Guru Indonesia Dompet Dhuafa and teacher development at Sukma Bangsa School. A total of 327 primary school teachers have participated in the study which was designed based on survey model. The study was limited to primary school teachers due to different teacher needs of other school levels may be occurred. The data of this study were obtained by using a questionnaire comprised of 13 close-ended items in the form of the rating scale. Descriptive statistics include the percentage, frequency, mean, and standard deviation for data analysis. According to the study results, $84,1 \%$ of respondents chosen classroom management as the most important training content to learn. Another indication of the result is that the teachers also need to learn teaching and learning models, developmental psychology, teaching motivation, teaching and learning evaluation, teaching and learning media, technology-based learning, lesson plan, 2013 curriculum, classroom display, public speaking and literacybased learning that more than $50 \%$ teachers defined them as very important to learn. However, only $47 \%$ of respondents mentioned Classroom Action Research is very important to learn. Based on the results of this study, the designer of TDP suggested considering classroom management as the first priority to deliver in the TDP followed by teaching and learning models, developmental psychology, teaching motivation, teaching and learning evaluation, teaching and learning media, technology-based learning, lesson plan, 2013 curriculum, classroom display, public speaking and literacy-based learning. In addition, it has to pay more attention to the teacher's need level of Classroom Action Research that is still very low due to improving their motivation to do research.
\end{abstract}

Keywords: teacher development program, teacher's need, survey, training content, Indonesian primary school teacher.

\section{SEBERAPA PENTINGKAH MUATAN PROGRAM PENGEMBANGAN GURU SAAT INI BAGI GURU SEKOLAH DASAR?}

\begin{abstract}
Abstrak
Program pengembangan guru dinilai efektif jika muatan materi yang diberikan sesuai dengan kebutuhan guru. Penelitian ini bertujuan untuk mengetahui seberapa penting muatan pelatihan yang selama ini dibawakan dalam program pengembangan guru. Muatan pelatihan yang dimasukkan ke dalam daftar muatan pelatihan pada penelitian ini diambil dari Kelompok Kerja Guru (KKG), program School of Master Teacher yang diselenggarakan oleh Sekolah Guru Indonesia Dompet Dhuafa dan program pengembangan guru di Sekolah Sukma Bangsa. Sebanyak 327 guru sekolah dasar telah berpartisipasi dalam studi yang dirancang berdasarkan model survei. Penelitian ini terbatas pada guru sekolah dasar sebab kebutuhan guru pada jenjang pendidikan lainnya dapat berbeda. Data penelitian ini diperoleh dengan menggunakan kuesioner yang terdiri dari 13 soal tertutup dalam bentuk skala penilaian. Statistik deskriptif termasuk persentase, frekuensi, mean, dan deviasi standar
\end{abstract}


dihitung untuk analisis data. Studi ini menunjukkan bahwa manajemen kelas adalah konten pelatihan yang paling penting untuk dipelajari oleh guru sekolah dasar dimana sebanyak $84,1 \%$ responden memilihnya sebagai muatan yang sangat penting dipelajari. Indikasi lain dari hasil penelitian ini adalah bahwa para guru juga perlu belajar model-model pembelajaran, psikologi perkembangan, motivasi mengajar, evaluasi belajar mengajar, media pembelajaran, pembelajaran berbasis teknologi, rencana pelajaran, kurikulum 2013, display kelas, public speaking dan pembelajaran berbasis literasi dimana lebih dari 50\% guru mendefinisikannya sebagai materi yang sangat penting untuk dipelajari. Sebaliknya penelitian tindakan kelas masih dianggap belum begitu penting dimana hanya 47, $1 \%$ yang menilainya sangat penting untuk dipelajari. Berdasarkan hasil studi ini, perancang program pengembangan guru pada masa mendatang disarankan agar memprioritaskan manajemen kelas untuk disampaikan dalam program pengembangan guru, diikuti oleh model-model pembelajaran, psikologi perkembangan, motivasi mengajar, evaluasi belajar mengajar, media pembelajaran, pembelajaran berbasis teknologi, rencana pelajaran, kurikulum 2013, display kelas, public speaking dan pembelajaran berbasis literasi. Namun dengan melihat tingkat kebutuhan guru yang masih rendah terhadap penelitian tindakan kelas perlu menjadi perhatian agar minat guru untuk melakukan penelitian dapat ditingkatkan.

Kata Kunci: program pengembangan guru, kebutuhan guru, survei, materi pelatihan, guru sekolah dasar Indonesia.

\section{INTRODUCTION}

Teacher's role in educating, teaching and training is the key to transmit values, and to develop knowledge, technology, and skills (Usman, 2016). In performing their duties professionally, teachers need to have special skills and expertise in the field of teacher training (Badrudin, 2014). Teacher professionalism does not mean only covering professional competency, but also pedagogical, social and perso-nality (Sagala, 2009). Teacher as a pro-fessional has a job to help students to learn, hence they need to master knowledge base and the professional skills. They also need to teach based on experience and the wisdom practice (Arends, 2012).

However, the results of Initial Competency Test and Teacher Competency Test in 2012 showed a very low achievement. The average score in the Initial Competency Test before obtaining a professional certificate was 42.25 (scale 100 ), with the most spread of about 80-90 thousand on interval value 35-40. Only 8 from 33 provinces are worth more than the national average. In the meantime, online Teacher Competency Test results data found after obtaining a professional certificate showed a national average of 45.82 (scale 100), with a distribution of about 6070 thousand teachers at 42-43 interval scores. It was found there are only 7 of 33 provinces are above the national average (Udiutomo et.al., 2013).

In order to overcome the low competence of teachers, they need to obtain development program accordance with their needs. Increasing teacher competence is needed in overcoming the fundamental problems in the quality of education because competent teachers play a strategic role in achieving the quality of education (Basri \& Rusdiana, 2015). The development program is a need for teachers and it will give impact to their teaching. Teachers who receive adequate training and administrative support are able to acquire the knowledge and skills required to implement innovative edu-cation (Stein $\&$ Wang, 1988). Teacher training is one of the teacher's need for ongoing development. (Wahyudin, 2017). One of the examples is that the teachers who have got a development of a scientific inquiry training program successfully change their perception of science teaching and inquiry skills (Ertikanto et al., 2017).

Despite the fact that there were many teacher developments conducted, there 
were only a few numbers of the teacher who implements what they have got from those programs. One example was the development programs on 2004 competency-based curriculum, the observation result shows that most teachers did not implement this in their classrooms (OECD, 2015). In designing development program for the teacher, there are some points the designer has to consider related to the planning, process, and evaluation, but the very first things to decide is what knowledge the teacher needs to develop.

The main focus of the professional development program is whether the program answers the needs of teachers and how much it builds and retain the knowledge and skills of teachers (Clark, 2015). Adult education will only be effective in the sense of generating behavioral change if the content and process of education match their needs (Lunandi, 1986).

This study focused on the primary school teacher's need of training content in the development program because teacher's need from other school levels might be different. Primary school is the great first step in developing learners' attitudes to enable them to develop their behavior patterns in the future. Rodgers (1975) stated elementary schools are responsible for providing basic skills in communication and computing to become the foundation for future learning. By accommodating the needs of learners as individuals, potential, uniqueness, group associations and the emotional stability of learners, they will help to think realistically and critically to make it easier for them to adapt in the future. Because education at primary school level is very different from other education levels, then the teacher's development program is also different.

A big number and a variety of development program for teachers have been done for improving teacher's teaching capacity. One of the teacher development program conducted for primary school teachers in Indonesia is professional learning community called Teachers
Working Group in which the teachers learn the development of syllabi and lesson planning, discussion of subject matter, the development and practice of active and innovative teaching methods, the design of teaching aids, and student testing and achievement (Chang et al., 2014). This program type is accessible for most Indonesian teachers because it can be conducted independently by each group. Another form of the development program for primary school teachers names School of Master Teacher which conducted by Sekolah Guru Indonesia Dompet Dhuafa. The training content consists of teaching media, classroom display, class rules, authentic assessment, literacy-based learning, rewards, and classroom action research (Jayanti \& Ali, 2017). Capacity development at Sukma Bangsa School is another example of the development program implementation in Indonesia. In this school, the teachers are developed through a learning community, virtual learning, writing, critical groups, mentoring, peer counseling, teacher exchange, classroom action research, conference, seminar, and sustainable development to improve teacher's capacity on using technology, writing, teaching resources, curriculum, lesson plan, literacy, research, and others (Bashori et al., 2015).

\section{METHOD}

This study used a quantitative approach aimed at identifying the training content that the primary school teachers need to get through professional development. It was conducted by the use of a selfconstructed survey questionnaire ba-sed on the literature review and the researcher's knowledge of primary school teacher professional development. The survey instrument comprised of 13 close-ended items in the form of Rating Scale, consisting of five scales, i.e., very important, important, moderately important, slightly important, not important. The instrument was piloted to 30 teachers and it was validated for reliability by applying Cronbach alpha. The Cronbach alpha value 
was defined reliable since the value was $0,853>0,6$. According to Ali (2014), if the alpha value is bigger than the $r$ table, then it is reliable.

\section{Participants}

The participant in this study was 327 Indonesian primary school teachers from six different Islands, i.e., Sumatera $(n=72$, $22.0 \%)$, Nusa Tenggara, $(\mathrm{n}=13,4.0 \%)$, Java $(n=156,47.7 \%)$, Sulawesi $(n=79,24.2 \%)$, Kalimantan $(\mathrm{n}=4,1.22 \%)$, and Papua $(\mathrm{n}=3$, $0.92 \%) .99$ of them were male $(30.3 \%)$ and 228 were female $(69.7 \%)$. The criteria sampling used in this study was random sampling that all the primary school teachers in Indonesia had the same chance to participate voluntarily.

\section{Data Collection and Analysis}

Data of the study were collected using a validated survey tool and it was distributed during the second semester of 2017. Descriptive statistics include percentage, frequency, mean, and standard deviation were calculated using a descriptive analyzing technique.

\section{FINDINGS AND DISCUSSION Findings}

This research addressed the main question on how important the training content that has been delivered in the teacher development program.

Table 1. The importance of training contents for the teacher to learn

\begin{tabular}{|c|c|c|c|c|c|c|c|}
\hline \multicolumn{2}{|c|}{ Training Contents } & \multirow{2}{*}{$\begin{array}{c}\begin{array}{c}\text { Very } \\
\text { Important }\end{array} \\
84.1\end{array}$} & \multirow{2}{*}{$\begin{array}{c}\text { Important } \\
14.1\end{array}$} & \multirow{2}{*}{$\begin{array}{c}\begin{array}{c}\text { Moderately } \\
\text { Important }\end{array} \\
1.8\end{array}$} & \multirow{2}{*}{$\begin{array}{c}\begin{array}{c}\text { Slightly } \\
\text { Important }\end{array} \\
0\end{array}$} & \multirow{2}{*}{$\begin{array}{c}\begin{array}{c}\text { Not } \\
\text { Important }\end{array} \\
0\end{array}$} & \multirow{2}{*}{$\begin{array}{c}\text { Frequency } \\
100\end{array}$} \\
\hline 1 & $\begin{array}{l}\text { Classroom } \\
\text { management }\end{array}$ & & & & & & \\
\hline 2 & $\begin{array}{l}\text { Teaching and } \\
\text { learning models }\end{array}$ & 81.7 & 17.1 & 1.2 & 0 & 0 & 100 \\
\hline 3 & $\begin{array}{l}\text { Public speaking } \\
\text { technique }\end{array}$ & 61.8 & 32.7 & 5.2 & 0.3 & 0 & 100 \\
\hline 4 & $\begin{array}{l}\text { Teaching } \\
\text { motivation }\end{array}$ & 72.8 & 22.9 & 4.0 & 0.3 & 0 & 100 \\
\hline 5 & $\begin{array}{l}\text { Technology- } \\
\text { based learning }\end{array}$ & 62.4 & 30.6 & 7.0 & 0 & 0 & 100 \\
\hline 6 & $\begin{array}{l}\text { Developmental } \\
\text { Psychology }\end{array}$ & 73.7 & 22.0 & 4.0 & 0.3 & 0 & 100 \\
\hline 7 & Lesson plan & 67.6 & 23.9 & 8.3 & 0 & 0.3 & 100 \\
\hline 8 & $\begin{array}{l}\text { Teaching and } \\
\text { learning } \\
\text { evaluation }\end{array}$ & 70.3 & 25.1 & 4.3 & 0 & 0.3 & 100 \\
\hline 9 & $\begin{array}{l}\text { Classroom } \\
\text { display }\end{array}$ & 56.0 & 35.2 & 8.6 & 0.3 & 0 & 100 \\
\hline 10 & $\begin{array}{l}\text { Teaching and } \\
\text { learning media }\end{array}$ & 70.9 & 26.3 & 2.7 & 0 & 0 & 100 \\
\hline 11 & $\begin{array}{l}\text { Classroom } \\
\text { action } \\
\text { research }\end{array}$ & 47.1 & 42.5 & 10.1 & 0.3 & 0 & 100 \\
\hline 12 & $\begin{array}{l}\text { Literacy-based } \\
\text { learning }\end{array}$ & 52.9 & 39.1 & 7.0 & 0.9 & 0 & 100 \\
\hline 13 & $\begin{array}{l}2013 \\
\text { curriculum }\end{array}$ & 63.9 & 24.5 & 10.7 & 0.9 & 0 & 100 \\
\hline
\end{tabular}

The findings indicate that classroom management is the most important that $84.1 \%$ participants mentioned it very important followed by teaching and learning models which got $81.7 \%$, and developmental psychology (73.7\%).
Generally, most of the training contents in table 1 are important for primary school teachers. However, there is one point which got less than 50\% score in "very important" column. It is number 11 (classroom action research) which got only $47.1 \%$. 
Table 2. Statistic Scale for the relationship of the items

\begin{tabular}{llll}
\hline & \multicolumn{1}{c}{ Training Content } & Mean & $\begin{array}{l}\text { Standard } \\
\text { Deviation }\end{array}$ \\
\hline 1 & Classroom management & 4.82 & 0.43 \\
2 & Teaching and learning models & 4.80 & 0.43 \\
3 & Public speaking technique & 4.68 & 0.52 \\
4 & Teaching motivation & 4.68 & 0.56 \\
5 & Technology-based learning & 4.47 & 0.66 \\
6 & Developmental Psychology & 4.56 & 0.61 \\
7 & Lesson plan & 4.58 & 0.67 \\
8 & Teaching and learning evaluation & 4.69 & 0.56 \\
9 & Classroom display & 4.36 & 0.67 \\
10 & Teaching and learning media & 4.55 & 0.62 \\
11 & Classroom action research & 4.51 & 0.72 \\
12 & Literacy-based learning & 4.44 & 0.67 \\
13 & 2013 curriculum & 4.65 & 0.59 \\
\hline
\end{tabular}

In table 2, mean score and standard deviation were analyzed and it shows classroom management gets the highest mean score (4.82) with the lowest standard deviation (0.43). Teaching and learning model is the second highest mean score (4.80) with the same standard deviation and it followed by teaching \& learning evaluation as the third highest mean score (4.69) with the standard deviation 0.56 .

\section{Discussion}

This study examined how important the training contents learned by primary school teachers in the development program. The survey tool included a quantitative component of 13 items was used to answer the research question. According to the study result, the most important training contents for primary school teachers is classroom management. These findings are in line with Arends (2012) which stated that the main difficulty faced by teachers in the first years of their teaching is classroom management. Moreover, this managing learners' behavior in the classroom is specifically become the greatest challenge for primary school teachers, hence they need more understanding on children for not being frustrated (Colverd \& Hodgkin, 2011).

The second important training content for teachers to learn is teaching and learning models. Arends (2012) identified effective teachers are they who can innovate their teaching with various learning models. Understanding student's developmental psychology is also a very need for teachers. Lang \& Evans (2006) suggested that it is a need for teachers to know and understand their students so that they can appreciate the diversity and apply a variety of instructional approach and activities. In addition, teachers need to have an increased understanding of how today's students learn, the skills that students need and to support the learning styles and skill models that students need to master (Arrington, 2014).

In this study, more than fifty percent respondents have also identified the importance of teaching motivation, teaching and learning evaluation, teaching and learning media, technology-based learning, lesson plan, 2013 curriculum, classroom display, public speaking and literacy-based learning. These study results are parallel by various empirical. Sapa'at (2012) highlight that motivation for the teacher is important to rebuild their passion for teaching so that they are able to overcome all the challenges. Another point that the development program should cover is teaching and learning evaluation. Retnawati, Hadi \& Mugraha (2016) found out in their study that the most Indonesian's teachers difficulty is their lack of under- 
standing in implementing the evaluation of the new curriculum.

Furthermore, understanding the use of teaching and learning media will help the teacher to deliver the lesson in a more effective way. Heinich, Molenda, \& Russel (1992) defined media as a tool to transfer information from the source to the receiver. Nowadays, the importance of technology cannot be denied. Isjoni \& Firdaus (2008) maintains the importance of instructional technology that the teachers expect to continue to take advantage of instructional technology that can benefit students. Besides that, before implementing the learning, instructional planning or lesson plan is one aspect that the teacher should prepare. Stronge (2007) concluded that organizing time, preparing teaching materials, designing activities, and other components of instructional planning are important for teachers to support the students successful in the future.

Additionally, understanding the curriculum, especially the new curriculum as it occurs in Indonesia for these recent years is a must for teachers. It is because the teachers' positive perception toward the curriculum is the starting point for the teacher to accept and be ready to implement the curriculum (Sulaiman, Sulaiman, \& Abdul-Rahim, 2017). Chatib \& Fatimah (2013) categorized classroom display as one of the important skills that the teacher needs to understand because it can be used to measure teacher's creativity, student's motivation to learn, the courage to perform, stimulate student's aesthetic sensitivity, the barometer of student-teacher cooperation, and as a promotion tool. Communication skill of the teacher is the key of effective teaching as it stated on Danim (2011), professional teacher's role to become a good communicator while also being a good listener and it is the core of effective learning. At last, literacy-based learning is also one the important training contents that the teacher needs through this study result. This idea comes up and becomes popular in Indonesia since the result of PISA (Program for International Student Assesment) shows very low achievement of Indonesian fifteen-year-olds on basic skills in reading or Mathematics below the OECD (Organization for Economic Co-operation and Development) average (OECD, 2015).

\section{CONCLUSION}

According to the study results, classroom management is the most important training content that Indonesian primary teachers need to learn. When teachers have more sources of knowledge to describe and teaching conditions are more conducive, they are more effective in promoting student learning (Darlinghammond, 2016). The findings of classroom management as the most important training content for teachers does not mean that teachers do not need to learn other materials. The results of study indicate that teaching and learning models, developmental psychology, teaching motivation, teaching and learning evaluation, teaching and learning media, technologybased learning, lesson plan, 2013 curriculum, classroom display, public speaking and literacy-based learning are also needed to learn by the teachers as the findings show that more than 50\% teachers defined them are very important to learn. Based on the result, the designer of teacher development program suggested considering classroom management and other training contents mentioned in this study as the consideration in deciding what to deliver in teacher training or other kinds of the development program.

\section{Acknowledgment}

As one of the awardees of Indonesia Endowment Fund for Education (LPDP), I would like to express my gratitude and heartfelt thanks to LPDP for the grant and to Prof. Dr. Dinn Wahyudin, MA. for all the help and support.

\section{REFERENCES}

Ali, M. (2014). Memahami riset perilaku dan sosial. Jakarta: Bumi Aksara. 
Arends, R. L. (2012). Learning to teach, Ninth Edition. New York: McGraw Hill.

Arrington, J. D. (2014). Creating 21st century classrooms: what district level instructional leaders know about leading 21st century learning. Presented to the Faculty of The Graduate College at the University of Nebraska In Partial Fulfillment of Requirements For the Degree of Doctor of Education Major: Educational Administration Under the Supervision of Professor Jody Isernhagen Lincoln, Nebraska.

Badrudin. (2014). Manajemen peserta didik. Jakarta: Indeks.

Bashori, K., Baedowi, A., Akbar, J., Sansrisna, Maulana, A., Zen, S.P., and Martunis. (2015). Pengembangan kapasitas guru: dari sekolah sukma bangsa untuk Indonesia. Jakarta: Pustaka Alvabet.

Basri, H., \& Rusdiana. (2015). Manajemen pendidikan dan pelatihan. Bandung: Pustaka Setia.

Chang, M. C., Shaeffer, S., Al-Samarrai, S., Ragatz A. B., de Ree, J., and Stevenson R. (2014). Teacher reform in Indonesia: the role of politics and evidence in policy making. directions in development. Washington: World Bank. Doi:10.1596/978-08213-98296.

Chatib, M. \& Fatimah, I.N. (2013). Kelasnya manusia: memaksimalkan fungsi otak belajar dengan manajemen display kelas. Bandung: Kaifa.

Clark, C. M. (2015). Teachers' evaluation of professional development in support of national reforms Tuba Gökmenoğlu, 25(4), 442-459.

Colverd, S., and Hodgkin, B. (2011). Developing emotional intelligence in the primary school. New York: Routledge.

Danim, S. (2011). Pengembangan profesi guru: dari pra-jabatan, induksi, keprofesionalan madani. Jakarta: Kencana.
Ertikanto, C, Herpratiwi, Yuniarti, T. \& Saputra, A. (2017). Development and evaluation of a model-supported scientific inquiry training program for elementary teachers in Indonesia. International Journal of Instruction, $10 / 3$, 93-108. https://doi.org/10.12973/iji.2017.103 $7 \mathrm{a}$

Heinich, R., Molenda, M., \& Russel, J. D. (1992). Instructional media and the new technologies of instruction: third edition. MacMillan.

Isjoni \& LN., Firdaus. (2008). Pembelajaran terkini: perpaduan Indonesia-Malaysia. Yogyakarta: Pustaka Pelajar.

Jayanti \& Ali, M. (2017, 9-11 October). Do the teachers practice their school of master teacher learning experiences in their real teaching?. Paper presented at The 3rd International Conference on Advances in Education and Social Sciences, Istanbul, Turkey. Retrieved from http://www.ocerint.org/adved17_epublication/papers/345.pdf

Lang, H. R. \& Evans, D. N. (2006). Models, strategies, and methods for effective teaching. Boston: Pearson.

Lunandi. (1986). Pendidikan orang dewasa. Jakarta: Gramedia.

OECD. (2015). Education in Indonesia: rising to the challenge. Paris: OECD Publishing. http://dx.doi.org/10.1787978926423 0750-en.

Retnawati, H., Hadi, S. \& Nugraha A.C. (2016). Vocational high school teachers' difficulties in implementing the assessment in curriculum 2013 in Yogyakarta province of Indonesia. International Journal of Instruction, 9/1, 33-48. 10.12973/iji.2016.914a

Rodgers, F.A. (1975). Curriculum and instructional in elementary school. New York: Mcmillan Publishing.

Sagala. (2009). Kemampuan profesional guru dan tenaga kependidikan: pemberdayaan guru, tenaga kependidikan dan masyarakat dalam 
manajemen sekolah. Bandung: Alfabeta.

Sapa'at, A. (2012). Stop menjadi guru. Jakarta: Tangga Pustaka.

Stein, M. K., \& Wang, M. C. (1988). Teacher development and school improvement: the process of teacher change. Teaching and Teacher Education, 4(2) 171-187. Great Britain: Pergamon Press.

Stronge, J.H. (2007). Qualities of effective teachers, second edition. Alexandria, VA: Association for Supervision and Curriculum Development.

Sulaiman, S., Sulaiman, T. \& Abdul Rahim, S. S. (2017). Teachers' perception of the standard-based english language curriculum in Malaysian primary schools. International Journal of Instruction, 10/3), 195-208. https://doi.org/10.12973/iji.2017.103 $13 \mathrm{a}$.

Udiutomo, P., Fatimah, R., Pardini, A., Puspitasari, D., \& Agustina, S. (2013). Besar janji daripada bukti: kebijakan dan praktik pendidikan Indonesia di era transisi demokrasi. Bogor: Dompet Dhuafa Makmal Pendidikan.

Usman, M. U. (2016). Menjadi guru profesional. Bandung: Remaja Rosdakarya.

Wahyudin, D. (2017). Curriculum development and teaching philosophy. Lambert Academic Publishing. 